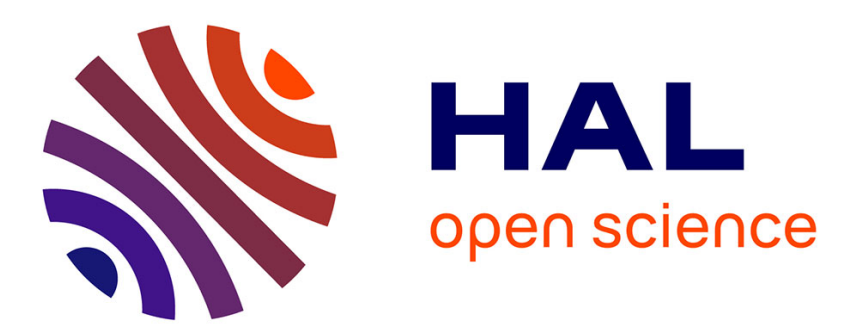

\title{
Contestation in Multi-Stakeholder Initiatives: Enhancing the Democratic Quality of Transnational Governance
}

\author{
Daniel Arenas, Laura Albareda, Jennifer Goodman
}

\section{- To cite this version:}

Daniel Arenas, Laura Albareda, Jennifer Goodman. Contestation in Multi-Stakeholder Initiatives: Enhancing the Democratic Quality of Transnational Governance. Business Ethics Quarterly, 2020, 30 (2), pp.169-199. 10.1017/beq.2019.29 . hal-03269421

\section{HAL Id: hal-03269421}

\section{https://hal-audencia.archives-ouvertes.fr/hal-03269421}

Submitted on 28 Jun 2021

HAL is a multi-disciplinary open access archive for the deposit and dissemination of scientific research documents, whether they are published or not. The documents may come from teaching and research institutions in France or abroad, or from public or private research centers.
L'archive ouverte pluridisciplinaire $\mathbf{H A L}$, est destinée au dépôt et à la diffusion de documents scientifiques de niveau recherche, publiés ou non, émanant des établissements d'enseignement et de recherche français ou étrangers, des laboratoires publics ou privés. 


\title{
Contestation in Multi-Stakeholder Initiatives: \\ Enhancing the Democratic Quality of Transnational Governance
}

Daniel Arenas (Universitat Ramon Llull), Laura Albareda (Lappeenranta University, Jennifer Goodman (Audencia Business School)

draft June 2019

[the final version of this article was accepted for publication in Business Ethics Quarterly]

\begin{abstract}
This article studies multi-stakeholder initiatives (MSIs) as spaces for both deliberation and contestation between constituencies with competing discourses, and disputed values, beliefs, and preferences. We review different theoretical perspectives on MSIs, which see them mainly as spaces to find solutions to market problems (economic approach), as spaces of conflict and bargaining (political approach), or as spaces of consensus (deliberative approach). In contrast, we build on a contestatory deliberative perspective, which gives equal value to both contestation and consensus. We identify four types of internal contestation which can be present in MSIs procedural, inclusiveness, epistemic, and ultimate-goal—and argue that embracing contestation and engaging in ongoing revision of provisional agreements, criteria, and goals can enhance the democratic quality of MSIs. Finally, we explore the implications of this perspective for theorizing about the democratic quality in MSIs and about the role of corporations in transnational governance.
\end{abstract}

\section{Keywords}

Transnational governance; multi-stakeholder initiatives; deliberative democracy; contestation; meta-consensus. 


\section{Contestation in Multi-Stakeholder Initiatives: \\ Enhancing the Democratic Quality of Transnational Governance}

\section{INTRODUCTION}

Over the last two decades, the liberalization of markets and the repeated failures to reach ambitious intergovernmental agreements to tackle "grand challenges" have led to the emergence of transnational private regulation (Bartley, 2007; Brunsson, Rasche, \& Seidl, 2012; Djelic \& Sahlin-Andersson, 2006; Turcotte, Reinecke, \& den Hond, 2014). Multi-stakeholder standardsetting initiatives (often simply called MSIs) have become a widespread experimental mechanism of transnational private regulation for several complex environmental and social challenges such as deforestation, unsustainable palm oil, fair trade, and lack of transparency in the extractive industry. The evolution of these initiatives has attracted the interest of organization scholars (Brunsson et al., 2012; Turcotte et al., 2014), deliberative democracy theorists (Dryzek, 1999; Bäckstrand, 2006), and business ethicists interested in the political role of corporations (Matten \& Crane, 2005; Scherer, Palazzo, \& Baumann, 2006; Scherer \& Palazzo, 2007; Scherer \& Palazzo, 2011). Different aspects such as MSI emergence and proliferation (Detomasi, 2007), convergence (Turcotte et al., 2014), their external legitimacy (Mena \& Palazzo, 2012), accountability (Hussain \& Moriarty, 2018), and outcomes (Fransen \& Kolk, 2007; Gilbert, Rasche, \& Waddock, 2011; Pinske \& Kolk, 2012) have been extensively discussed and researched. By contrast, the analysis of how MSIs deal with internal contestation has been relatively neglected and underestimated, although such contestation may be inevitable in processes involving civil society actors, companies, governments, and inter-governmental organizations, with contrasting or disputed discourses, values, and beliefs. This article aims to 
fill this void by studying contestation in MSIs and by providing a better understanding of the seemingly contradictory situation that makes contestation problematic for the functioning of MSIs, but at the same time necessary. On the one hand, if democracy is understood as involving deliberation (Habermas, 1994, 1995; Gutmann \& Thompson, 2004) and if inclusiveness is one of its criteria (Nanz \& Steffek, 2005), contestation might be a sign and a condition of the democratic quality of an MSI; as such, it should be expected and welcomed. Yet, on the other hand, strong internal contestation can cause the collapse of deliberation and stand in the way of effectiveness, even more so for entities designed to address "grand challenges".

Recent critical literature in corporate social responsibility has warned that MSIs can be used by corporations to further enhance power asymmetries against vulnerable stakeholders (e.g. local communities) (Banerjee, 2017) or that through MSIs corporations acquire a supervising role that makes them less accountable (Hussain \& Moriarty, 2018). Yet, it is also undeniable that MSIs build on some level of cooperation between organizations from different sectors and create spaces, albeit imperfect ones, for some discussion, deliberation, and contestation. There are also increasing expectations for the further democratization of these mechanisms of transnational governance. Moreover, given that in a Post-Westphalian political order (Scherer, Palazzo, \& Matten, 2009; Santoro, 2010) their sudden disappearance or their overhaul by a legitimate overarching authority are unlikely, it is important to review how MSIs build their own governance and procedural rules (Schouten \& Glasbergen, 2011) which seem (or claim) to embed some democratic features (e.g. voting rules, representation rules, inclusiveness of different sectors on equal footing, deliberation on ultimate goals). So, while MSIs might still be far from the expectations, they have anticipated the need to develop some 
democratic governance practices and are worthy of consideration as part of the broad range of experimentations in deliberative forums referred to by Dryzek among others (Dryzek, 2010).

This article builds on an expanded version of deliberative democracy (Mansbridge, Bohman, Chambers, Estlund, Føllesdal, Fung, Lafont, Manin, \& Martí, 2010; Bächtiger, Niemeyer, Neblo, Steenbergen, \& Steiner, 2010; Bächtiger, 2011; Dryzek, 2010; Chambers, 2003), which in contrast to other versions gives much more importance to contestation and moves away from a "consensus-based teleology" (Chambers, 2003). This perspective also proposes studying deliberative democracy through analyses of real deliberative forums and events (Niemeyer, 2011). Using this perspective, in this article we argue for the need for contestation in MSIs, offer a characterization of some types of contestation present within MSIs, and suggest how they can be managed. To better understand the puzzle that internal contestation poses for MSIs, we resort to the concept of meta-consensus (Dryzek, 2010; Niemeyer \& Dryzek, 2007). When the outcomes expected from deliberation are the subject of disagreement, and rational consensus proves unachievable, meta-consensus is a basic agreement about some fundamental principles that can facilitate ongoing contestation and deliberation. In studying how the combination of contestation and meta-consensus takes place in MSIs, the present article aims to advance our understanding about the democratic quality of MSIs (Schouten \& Glasbergen, 2011). We also propose to extend the definition of MSIs to take into account the dynamic of ongoing revision as one of their characteristics, and thus conceptualize them as both contestatory and deliberative spaces seeking to develop progressive provisional agreements, instead of ultimate solutions.

The structure of the article is as follows. First, we review three main theoretical approaches on MSIs to show how they account for tensions and contestation. We then introduce 
a contestatory deliberative perspective (Dryzek, 1999, 2010; Niemeyer \& Dryzek, 2007;

Bächtiger, 2011) to explore the positive role of contestation in MSIs. We present four types of contestation - procedural, inclusiveness, epistemic, and ultimate-goal contestation-which can emerge in MSIs from differences in beliefs, values, and expectations. We illustrate them with recent episodes from four well-known MSIs: the Extractive Industries Transparency Initiative (EITI); the Roundtable on Sustainable Palm Oil (RSPO); Fairtrade International; and the Forest Stewardship Council (FSC). We recognize the seemingly contradictory situation in which contestation is necessary, but it also potentially constrains the continuation of deliberation and the advancement of an MSI's goals. Later, we discuss how meta-consensus helps overcome this puzzle, and how, in combination with contestation, can enhance the democratic quality of MSIs. This leads us to outline how meta-consensus can be used to manage the four types of contestation. Finally, we explore the implications for the role of business as a political actor in a globalized society and suggest possibilities for future research.

\section{PERSPECTIVES ON MSIS AND CONTESTATION}

A wide range of names have been used to refer to MSIs (see Moog, Spicer, \& Böhm, 2015: 470; Mena \& Palazzo, 2012: 533) and a variety of initiatives can fall into this broad category. In this article, we follow authors who focus on initiatives that share the following characteristics as being the most relevant for the debate on transnational private governance (Mena \& Palazzo, 2012): a) they are spaces for dialogue, exchange, and learning among actors from different sectors (corporate and non-corporate such as governments and civil society organizations), occurring beyond the boundaries of the nation-state; b) these different actors can participate, at least in principle, on an equal footing and are represented in the initiatives' 
governance mechanisms; c) they establish standards for corporate activity and/or government accountability, including codes of conduct, guidelines, and rules; and d) they usually implement monitoring mechanisms and third-party verification systems to ensure that the regulated entities comply with the standards, often issuing certifications for those who do. Following common practice, we refer to our object of study as "MSIs", although it might be more appropriate to call them "multi-stakeholder standard setting initiatives". They should be distinguished from "shared governance procedures" where the authority emanates from states (Cashore, 2002) and from "business-driven self-regulation", which are governed mainly by for-profit organizations that develop their own standards without including other sectors (Fransen, 2012; Hafler, 2010; Marques, 2013).

Recognizing that political scientists have studied MSIs as a form of global governance under different lenses (Cashore, 2002; Bartley, 2007; Fransen, 2012), it is useful to start with Turcotte, Reinecke and den Hond's (2014) classification of three main perspectives. In the following, we briefly review them, complementing these authors' analysis with the question of how these perspectives take into account contestation within MSIs. Following Turcotte et al., we call the first two approaches "economic" and "political", while for the third we use the label "deliberative" (instead of "idealist") to remain closer to the terms used by the proponents of this view.

The "economic" perspective looks at MSIs mainly as providing solutions to industry and firm problems. Firms would make the strategic choice to establish or join MSIs to minimize the influence of other stakeholders, secure long-term supplies of raw materials, and anticipate or prevent "hard" regulation. As economically rational actors, they would make cost-benefit analyses, considering the need to protect firm reputation, differentiate the brand, provide 
credible information for consumers and watchdog groups, and limit competition (Bartley, 2007; Potoski \& Prakash, 2009). This perspective does not tackle the question of contestation directly, just as it is not concerned about whether all the parties affected by an issue are integrated in an MSI and whether consensus is reached. However, it would predict that conflicts would appear as the result of different economic interests and would pose the risk of increasing costs. Thus, this perspective takes power asymmetries and differing interests as given and unquestioned; and would recommend businesses to pay attention to whether other stakeholders control some key resources vital for firm activity. Rather than embracing contestation within the MSI as an opportunity to advance on its mission, actors would do a cost-benefit analysis and might even choose to create a competing standard. This multiplicity of standards could be to the detriment of addressing the original challenge.

The "political" perspective sees standards coming from MSIs as "negotiated settlements" (Bartley, 2007: 299) among different constituencies: non-governmental organizations (NGOs), firms, and states. Whereas the economic approach puts the emphasis on firms and the industry, this perspective considers other actors, such as states and social movements, to be essential in the emergence and maintenance of these new forms of global governance. According to this view, the actors' different interests, goals, or beliefs regarding the issue at hand (e.g. deforestation, water, fair trade) are shaped by "complex processes of contestation, negotiation and bargaining" (Turcotte et al., 2014: 9). Thus, conflict and power differences between actors with divergent interests and competing frames are fundamental for this approach (Bartley, 2007). Nonetheless, most of the attention has been on the external conflict that leads to the emergence of private governance initiatives, neglecting the internal contestation that may arise in the ongoing operation of such initiatives. When they do look at internal contestation, studies have 
focused on struggles among MSIs' participants that question each other's legitimacy (Moog et al., 2015), losing sight of other types of contestation that may emerge internally such as those we will discuss later in this article.

As part of the "political" approach, we include critical perspectives (not emphasized by Turcotte et al., 2014) that study relations between firms and stakeholders, as well as MSIs, using “agonistic pluralism” (Dawkins, 2015) and "neo-Gramscian” lenses (Levy \& Egan, 2003; Moog et al., 2015). Following authors like Chantal Mouffe (1999), this perspective acknowledges relations of power, contestation, and antagonism as ineradicable, positive dimensions in the public sphere and criticize the "deliberative" approach (see below) as repressing spontaneity and difference. In some cases, this includes questioning the legitimacy of the whole enterprise of establishing MSIs, insofar as they are considered tools for distraction or containment to prevent marginalized groups from voicing their opposition to firm activities (Banerjee \& Sabadoz, 2014; Banerjee, 2017). However, this perspective risks presenting agreements always as nothing more than impositions and concessions. Hence, it can result in an absence of indications as to how to move beyond contestation or use contestation productively (for exceptions see Dawkins' [2015] work on arbitration and Mouffe's suggestion of mobilizing passions to promote "democratic designs" [Mouffe, 1999: 756]).

Finally, the "deliberative" perspective considers MSIs as spaces of participatory multistakeholder deliberation; that is, as a process of intersubjective articulation of diverse ethical viewpoints and preferences to achieve a rational consensus and legitimate decisions. Like the political approach, this perspective stresses that a multiplicity of actors are involved in elaborating soft-regulation and establishing MSIs, and that multi-national corporations have become political actors in the new political order, often referred to as Post-Westphalian 
(Scherer, Palazzo, \& Matten, 2009; Santoro, 2010). Yet, in contrast to the previous approach, it assumes that actors may engage in nonstrategic communication and change their positions and expectations through communication and dialogue with others to reach legitimate, mutually acceptable decisions. Rather than focusing on clashes of interest, the emphasis is on a rationally achieved consensus, emerging from free, open, and non-coercive deliberative discussion. Following Habermas’ deliberative democratic perspective (Habermas, 1994; 1995; [1995] 2015), scholars claim that to arrive at legitimate criteria to regulate complex environmental and social issues, MSIs need to be based on non-coercive, transparent, and rational deliberation among all affected parties (Gilbert \& Rasche, 2007; Scherer \& Palazzo, 2007; Mena \& Palazzo, 2012). Yet, while integration of the affected stakeholders and consensus are fundamental for this approach, it does not usually devote much time to analyzing contestation, nor does it reflect on its productive aspects. This weakness has been noted in recent deliberative democracy literature: "If deliberation does not lead to consensus (a rare occurrence), how is conflict to be dealt with? Deliberative democrats are quick to point out how conflicting parties should engage with each other, but have less to say about how agreements short of consensus or a vague notion of workable agreement are to be reached" (Smith, 2009: 11).

Expanding on the metaphors used by Bartley (2007), we could summarize these three prevailing approaches to MSIs as presenting different types of spaces: a space for market solutions; a space of conflict and bargaining; and a space for legitimate and rational consensus. These three main theoretical approaches clearly take different views on contestation, as summarized below in Table 1. Both the economic and the political perspectives (either implicitly or explicitly) take contestation as unavoidable, but do not usually place internal contestation at the center of their analysis of MSIs. They typically refer to external contestation 
to firm activity and do not offer much insight on how it leads to constructive outcomes. The deliberative approach focuses on the pursuit of consensus among actors but does not explain how to make it compatible with contestation. In the next section, we explore an alternative route.

\section{A CONTESTATORY DELIBERATIVE APPROACH}

As recently reviewed by Sabadoz and Singer (2017), several deliberative democrats have been advocating in recent years for an expanded version of deliberative democracy (Mansbridge et al., 2010; Bächtiger et al., 2010; Bächtiger, 2011; Dryzek, 2010; Chambers, 2003). What is significant, in our view, is that in contrast to the classical version this tendency gives much more importance to contestation, moving away from the idea that "deliberation converges on consensus" (Dryzek \& Niemeyer, 2010b: 85; Chambers, 2003), and proposes studying deliberative democracy through analyses of real deliberative forums and deliberative events (Niemeyer, 2011). It emphasizes that deliberation requires confrontational and adversarial processes by which different groups and participants "passionately engage with each other and go into the heart of the matter by persistently questioning and challenging each other's proposals" (Bächtiger, 2011: 7; see also Markell, 1997; Brady, 2004). This expanded version concludes that "deliberation ought to make less powerful actors more aware of their interests and, when interests conflict, increase their perception of the conflict" (Mansbridge et al, 2010: 69) and that "[o]ne purpose of deliberation should be to clarify conflict as well as commonality" (Ibid: 75).

The approach, which after Bächtiger and Dryzek we call a "contestatory deliberative" approach, agrees with the criticism that deliberation, especially if it focuses on reaching 
consensus, may lead to homogenizing discourses, stifling spontaneity, and marginalizing the voices of powerless actors (Fraser, 1997). Insofar as consensus is understood in terms of unanimity, it might not only be unattainable but it can also go against ongoing or future deliberation: it implies a closure, leads to conformism, and prevents new opinions from being voiced (Friberg-Fernros \& Schaffer, 2014). This approach accepts other forms of language (storytelling, appeals to emotions, rhetorical devices) and moves away from an exclusive focus on the language of "reason" to a focus on mutual justification. It thus emphasizes that deliberative democracy thrives on the inescapable pluralism of viewpoints, procedures, perspectives, values, judgments, and discourses in the public sphere (Dryzek, 2000). Yet, at the same time, just like the classical version of deliberative democracy, it is a normative theory in that it suggests ways to enhance democracy and criticize existing institutions. It focuses on the communicative processes of opinion and will formation among all those who are subject to the decision, prior to voting and other aggregative mechanisms; and excludes coercive power. The contestatory deliberative approach provides an alternative to the three perspectives seen above to analyze mechanisms of transnational governance such as MSIs, insofar as it values positively both deliberation and contestation. Following this approach, "democracy is not something that should be treated as either present or absent, but rather a matter of degree, and always a work in progress. In this light it makes more sense to think in terms of processes of democratization rather than models of democracy that can be either present or absent" (Stevenson \& Dryzek, 2014: 6). From this perspective, the claims that MSIs can be further democratized and that this is a dynamic process including internal contestation do not appear far-fetched. 
While other scholars have taken into account indicators for democratic quality such as the inclusion of a wide variety of points of view and discourses, the transparency in the procedures, respect for others, elaboration of the justification of one's position, and access to information, among others (Steiner, Bächtiger, Spörndli, \& Steenbergen, 2004; Nanz \& Steffek, 2005; De Vries, Stanczyk, Ryan, \& Kim, 2011), ${ }^{\mathrm{i}}$ the contestatory deliberative approach reminds us that disagreement and conflict are also necessary for deliberative processes. In other words, contestation among the parties involved can be considered as indispensable political episodes that contribute to the democratic quality of these institutions. In addition to internal conflict, this perspective also acknowledges the importance of a wider deliberative system (Dryzek \& Stevenson, 2011) that: (1) grants intrinsic value to interactions and debates in an external "public space" that is often critical of what is happening in the "empowered space" (in our case, the MSIs); and (2) defends the transmission of discourses from one space to the other, even if this happens in an "unregulated" or non-institutionalized way (Baur \& Arenas, 2014). As a consequence, this approach leads us to focus on the evolution of MSIs, rather than on their emergence and outcomes (as done by the other approaches), to search for new insights into the question of how MSIs can achieve higher democratic quality.

Finally, this approach can help solve the puzzle by which contestation is both necessary and something that needs to be overcome. It departs from the view that interactions can always be explained exclusively in terms of power, manipulation, or co-optation, and that individuals or groups can never come to some provisional, mutually acceptable agreements. To solve the difficulty of encouraging contestation without provoking the collapse of deliberation, Dryzek and his colleagues use the notion of meta-consensus, which they understand as a "relaxed version of consensus" (Niemeyer, 2011: 105), based on a common agreement about basic values 
and beliefs concerning what is appropriate in deliberation and the nature of the issue contested. Meta-consensus on some principles, such as the right to defend one's ideas and leave coercion aside, is considered necessary to engage in communication and deliberation, even without reaching unanimity on particular issues. The pursuit of legitimate provisional agreements and compromises is also part of the contestatory deliberative approach. Later in this article, we will explore how some types of meta-consensus are necessary for MSIs. The four perspectives on MSIs which we have presented - economic, political, deliberative, and contestatory deliberative- are summarized in Table 1.

Insert Table 1 around here

\section{TYPES OF CONTESTATION IN MSIs}

Having argued that, from a theoretical standpoint, a contestatory deliberative approach allows for the appreciation of contestation as being not incompatible but beneficial for deliberation, in this section we argue that, empirically, MSIs face episodes of internal contestation that do not necessarily paralyze them or prevent deliberation. While deliberative scholars have focused on rational consensus as unanimous agreement, we move beyond this view to include contestation as evidence of democratic pluralism and deliberation in MSIs. Now, MSIs can encounter different types of internal contestation, and they can respond to such episodes in different ways.

Without intending to exhaust all possibilities, we suggest a preliminary categorization of four different types of internal contestation. These types reflect increasing levels of complexity ranging from disputes about process to disputes about objectives. These are not exclusive 
categorizations, since episodes of internal turmoil and/or confrontation may often contain more than one type of contestation. We analyze them separately and provide an example of each for conceptual clarity. While the protagonists (and sympathetic bystanders) might experience these episodes with anxiety, we emphasize the positive aspects, insofar as contestation is productive, and even necessary, for democratic deliberation in MSIs. If these tensions did not occur, the democratic quality of MSIs would deteriorate and they could become private clubs or stale bureaucracies. Nonetheless, it could be argued that if these different types of contestation were to occur simultaneously in the same MSI for a long period of time, the survival of the MSI could be in jeopardy. This reinforces the idea of the seemingly contradictory situation in which contestation is both a necessity and a difficulty, or a risk, as it will be discussed in the next section.

The types of contestation that we propose have to do with how the MSI is governed, who participates (or what discourses are heard), what is happening (or might happen) in terms of the social and environmental impact of the agreements reached, and what is the MSI for (or what is its purpose). We call them procedural contestation, inclusiveness contestation, epistemic contestation, and ultimate-goal contestation. This categorization, which is a preliminary application of a contestatory deliberative approach to MSIs, reflects some elements from the work of Niemeyer and Dryzek (2007) and Dryzek (2010) as well other authors mentioned below. We draw on recent episodes from some well-known MSIs for illustrative purposes. These illustrations are useful for drawing attention to aspects of the phenomenon studied in this article. Table 2 provides an overview of the four MSIs from which the examples are taken: the Extractive Industries Transparency Initiative (EITI), the Roundtable on Sustainable Palm Oil (RSPO), Faitrade International, and the Forest Stewardship Council (FSC). 


\section{Procedural Contestation}

Procedural contestation occurs when there is no agreement on the procedures by which the MSI should govern itself, make decisions, and conduct operations. It can also arise when the procedures previously agreed by the members of the MSI are breached; or are perceived as having been breached. Such procedures are typically stated in formal documents and can include governance rules for nominating new members, voting procedures, or how to deal with noncompliance of members. The importance of procedural issues for deliberation has often been highlighted by political theory scholars as contributing to democratic quality (Diamond \& Morlino, 2004), but also by scholars in other fields, such as organizational justice, as enhancing institutional legitimacy, trust building, and voluntary cooperation (Cropanzano, Bowen, \& Gilliland, 2007). If procedural breaches did not provoke contestation and a disregard for previous agreements went unchallenged, ultimately this would amount to a degradation of the democratic quality of the MSI and further cooperation would be less likely. Thus, a lack of consensus on procedures can stimulate further deliberation about how to improve them. The following EITI episode offers an illustration of procedural contestation.

\section{EITI: Responding to Breaches}

Formed by governments, industry, and civil society organizations (CSOs), the EITI was established in 2003 with the aim of increasing transparency over payments and revenues in the extractive sector (EITI, 2017), after accusations that the sector contributed to the so called "resource curse" (Sachs \& Warner 2001). ${ }^{\text {ii }}$ At the Global EITI Conference held in Lima in 
February 2016, a controversy arose that led to over 100 civil society representatives boycotting the meeting. The boycott was prompted by the Chair's acceptance of a candidacy of a civil society representative to the Board (PWYP, 2016). The nomination did not follow the established EITI procedure for CSOs to self-select their representatives (EG Justice, 2016) and was instead made directly by a board member (Economist, 2016). The standard process establishes that the CSO coalition Publish What You Pay (PWYP) would manage the nomination process. Although the direct nomination in question was finally withdrawn, the fact that due to the boycott no CSO was in attendance called into question decisions made during the conference, including the adoption of the 2016 EITI Standard for Accountability (PWYP, 2016; EITI, 2016).

The EITI board meeting, which followed closely after the Global EITI Conference, dedicated time to discuss the episode. The incoming executive of PWYP gave a review of the events leading to the Global EITI Conference and put forward five points to remedy the situation which included a revision of the EITI Articles of Association to address governance gaps and transparency in the nomination process. The responses of the other board members from corporations and governments were broadly supportive: for example, the US government representative told the chair "it was important to acknowledge that some serious procedural errors were made during the members' meeting and that the consensus building efforts of the EITI could only work if all constituencies were present” (EITI, 2016). Finally, it was agreed that the five points raised by PWYP would be considered in the following Global Conference. Thus, the way to move forward was to accept discussing an improvement of the procedures.

While the contestation about the nomination process may appear easy to resolve, it was not trivial in that it affected one of the fundamental organizing principles, which was also key 
for the EITI's success (Frynas, 2010), namely: the participation of all stakeholders in seeking solutions. Building capacity among civil society has been noted as one of the EITI's strengths (Aaronson, 2011) and the opportunity that the EITI provides for CSOs to sit at the same table as policy makers in the discussion on the extractives industry and its revenues is essential (Ölcer, 2009). The absence of the CSOs at the Global EITI Conference, which is held only once every two to three years, signified a considerable setback for the organization.

Since improving governance and transparency is specific to the EITI's overall mission (Agbiboa, 2012; Haufler, 2010) and since governance at the board level becomes the exemplary model for all the national multi-stakeholder groups of the EITI, breaches in the accepted procedure caused all the more outrage. Thus, the issue took on a symbolic meaning: if the board itself was unable to abide by its own governance processes, it did little to inspire the optimal functioning of the rest of the organization. This episode provides an illustration of the importance of developing and maintaining clear governance procedures for the successful development of MSIs (Zeyen, Beckmann, \& Wolters, 2014). The contestatory deliberative approach sketched above also draws our attention to the fact that internal contestation is necessary and has a positive impact on democratic quality of MSIs. While an episode such as this would be understood under the lenses of the "political" approach as hiding a conflict about different interests and as part of the bargaining concerning quotas of power, the contestatory deliberative lens discloses another aspect: that through contestation members of EITI can provide mutually acceptable arguments to improve procedures and that this makes the continued functioning of the MSI possible. 


\section{Inclusiveness Contestation}

This type of contestation can take two forms: inclusiveness of representation and of discourses. The former refers to the participation of different stakeholders in the MSI. For example, contestation could arise about which stakeholders should be represented or become members, and also what proportion of overall representation they should have in the governance structure. In addition to being one of the fundamentals of deliberative democracy, the literature on organizational justice also stresses that all concerned stakeholders should be represented in decision-making (Cropanzano et al., 2007). The second type of inclusiveness relates to the acceptance within the MSI of critical and disputed discourses, independently of how they are formally represented. Questions may arise as to whether the MSI is the right forum for voices perceived as too critical, or which is the appropriate way to present one's positions inside this forum. As indicated above, some critical scholars are concerned that MSIs may curtail some types of discourses for not having the appropriate rhetorical form, thus excluding marginalized groups (Dawkins, 2015; Levy \& Egan, 2003). Contestation about the exclusion of some voices, especially those of affected stakeholders, can push MSIs to become more inclusive, and ultimately improves their democratic quality. If such contestation did not exist, MSIs could run the risk of becoming private clubs, more concerned with defending their members' interests than addressing larger social or environmental challenges. Thus, a lack of consensus can stimulate further deliberation about increasing inclusiveness of representation and discourses. A dispute among members of the RSPO about how to deal with critical voices is an example of inclusiveness contestation. 
RSPO: Publicly Criticizing the MSI

The RSPO was founded in 2004 by the World Wide Fund for Nature (WWF), Unilever, Migros, Aarhus United Ltd., Karlshamns, and the Malaysian Palm Oil Association (MPOA). Today it includes many industry stakeholders and NGOs with the goal of promoting the sustainable production of palm oil and reducing the severe environmental impacts of oil palm plantations (e.g., loss of biodiversity, destruction of wetlands, deforestation, forest fires and air and water pollution), as well as their negative social impacts (e.g., abusive working conditions and the uprooting of indigenous communities). The episode that we report occurred in the $10^{\text {th }}$ General Assembly, held in Medan (Indonesia) in November of 2013 during the discussion of a resolution to amend the RSPO code of conduct. Expressing concerns that certain members were publicly criticizing the functioning of the certification process, the resolution included two parts: it proposed (1) that all members who publicize negative aspects "must concurrently with equal effort publicize that RSPO certified sustainable palm oil is a solution to this negative aspect" (RSPO, 2013); and (2) that "members must abstain from any association with external organizations making references or implying negative aspects of the RSPO standard" (RSPO, 2013).

This proposal sparked an animated debate among participants in the General Assembly. The head of sustainability and quality management from a palm oil producer explained the resolution by saying that "when someone says something negative about the RSPO you don't go and publicly support it." In his view, one of the reasons for the amendment was that "we don't want you to go outside to create confusion. Otherwise why become an RSPO member?" One representative from a social/development NGO replied that the amendment went against freedom of expression. Another NGO member provocatively asked whether this amendment 
would also apply to company membership in industry associations if the industry association criticized the RSPO. Others expressed concerns that this could prevent the submission of complaints to the Complaint Panel of the RSPO, and questioned whether the resolution would also mean that companies that were certified by the RSPO would immediately cease sourcing palm oil from uncertified companies (a point that was denied by the proponents). One member claimed that meeting external critical stakeholders, like Greenpeace, provided valuable insights for discussion within RSPO. In the end, the resolution was defeated as $67 \%$ of those attending voted against it.

In addition to mixed interpretations of the expression "association with external critical members," at stake in this debate was the inclusive character of the RSPO; in this case, the inclusiveness of discourses. For some members (mainly NGOs and retailers), having contacts with external critics and being open to their views are essential for the MSI to draw on a diversity of opinions. However, others (typically palm oil producers) believe that the RSPO is weakened if members do not counter-argue criticisms by stating that the RSPO is the best solution to current challenges. Additionally, some members might have felt that the resolution was an attempt by other members to tighten control over them, which generated mistrust of their motives.

As this episode illustrates, a natural tendency of an organization might be to close itself off from outside criticism to gain effectiveness. However, limiting the association with external critics clearly goes against inclusiveness, eroding democratic quality, and in turn, the legitimacy of the MSIs. Expecting members of the MSI to be constant advocates might also be difficult, since some of them may perceive that their loyalty to the goals of the MSI entails publicly criticizing some aspects. A contestatory deliberative perspective draws our attention to the fact 
that a confrontational debate led the general assembly to clarify positions and ultimately to arrive at a provisional agreement concerning inclusiveness. By contrast, the classic deliberative democracy approach would overlook the positive effects of such contestation; and the "political" approach, with its emphasis on conflict as simply hiding power struggles, would not take seriously the possibility of members to provide mutually acceptable arguments about inclusiveness and the legitimacy of the MSI. Alternatively, an economic perspective would focus on why and how businesses would fight (perhaps even threatening to abandon the MSI) against the inclusion of external voices as it can represent a risk.

\section{Epistemic Contestation}

The third type of contestation stems from different understandings about "how actions affect values in cause and effect terms" (Niemeyer and Dryzek (2007: 502); for example, about how a community or the environment is directly or indirectly impacted by certain business and government activities regulated by the MSI and whether this impact is in line with the values of the MSI. Questioning, disputing, and arguing about facts and about the consequences and costs of different alternatives are important aspects of contestatory deliberation (Bächtiger, 2011). If there were no disagreements about the understanding of complex situations such as those related to social and environmental sustainability, this could signal lack of interest or, worse, manipulation. Thus, lack of consensus can lead to further inquiry about facts, about causes and effects, and about how they are related to certain values. Epistemic contestation is illustrated by a debate about how small farming cooperatives would be impacted by a change in the Fairtrade strategy. 
Fairtrade International: Conflicting Beliefs on Impact

Fairtrade International was formally launched in 1997 as a federation of different national fair trade organizations and producer networks in order to harmonize a worldwide Fairtrade standard and certification (Fairtrade International, 2011). The global fair trade movement aims to transform the rules of the global markets for local producers of some commodities in developing countries (e.g. coffee, cocoa, and sugar, among others), avoiding international mainstream buyers, and improving working conditions and economic benefits of small farmers organized in cooperatives (Fairtrade International, 2011; Haight, 2011; Moore, 2004).

Contestation arose within the organization after the presentation by Fairtrade USA (FTUSA) of the "Fair Trade for All Strategy", which aimed to expand the impact. According to Paul Rice, founder and CEO of FTUSA, this new fair trade model could reach over four million workers from large farms and independent small holders who were excluded from the system (Rice, 2012). The "Fair Trade for All Strategy" also aimed to increase awareness of Fairtrade around the world by reaching consumers beyond niche markets. This strategy changed the original Fairtrade model based on small farmer co-operatives as the only legitimate organizational form for producers (Haight, 2011). Critics claimed that the new FTUSA strategy would force small farmer co-operatives to compete with large plantations for market access, threatening the co-operatives and the Fairtrade movement itself (Gunter, 2012). The disagreement led to the departure of FTUSA from the international organization in late 2011 (Fairtrade USA, 2011). A joint statement was released announcing the separation: "Fairtrade International (FLO) and Fairtrade USA share a belief in the importance of empowering producers and workers around the world to improve their lives through better terms of trade. However, as we look to the future, we recognize that we have different 
perspectives on how best to achieve this common mission" (Fairtrade USA, 2011; Fairtrade International, 2011, 2012).

This situation represented a critical milestone in the development of this movement. It caused an intense internal debate among its constituencies around the world (Fairtrade International, 2012; Gunther, 2012; Modelo, 2014). An important source of contestation were different beliefs concerning the impact of the "Fair Trade for All Strategy". While FTUSA believed that including large farms and independent smallholders would allow the movement to grow without hurting small local co-operatives, Fairtrade International held that small local co-operatives would be dangerously harmed by making them compete with larger farm holders. In addition, there were different beliefs about how to increase impact, extend fair trade beyond a niche market, and transform the unfair global market system: while Fairtrade International preferred to adopt a lobbying strategy for new public regulation, FTUSA defended that a scalable business model would reach mainstream consumers promoting growth in fair trade products (Modelo, 2014). The contestatory deliberative approach, in contrast to a "political" perspective, would not see this contestation only as pure bargaining or self-interested negotiation, but would emphasize that it pushed the different parties to attempt to give mutually acceptable reasons in favor of one or the other policy in a transparent way, thereby enhancing the democratic quality of the MSI. One could argue that it also allowed the two organizations, Fairtrade International and FTUSA, to split in a relatively smooth, respectful way.

\section{Ultimate-goal Contestation}

The last type of contestation that we suggest emerges when different stakeholders do not share fundamental values, or have clearly differentiated value-priorities (Dryzek, 2010), despite their concern for and interest in solving a social or environmental challenge. This leads to 
contestation over the ultimate goal of the MSI. For example, some affected parties might prioritize social issues such as poverty alleviation, while others emphasize environmental issues such as endangered species. Although this type of divergence can lead to the breakdown of the MSI, its democratization requires moments of honest discussion about which goal should predominate. Disagreements at this level are the most complex to resolve and can become intractable because the value systems underlying different perspectives are deeply entrenched and closely linked to the actors' identity; thus, they become "arguably the toughest kinds of political issues" (Dryzek, 2005: 219). Yet, a lack of consensus on values can stimulate further deliberation about what is the ultimate goal of the MSI. We can observe ultimate-goal contestation in the following episode.

FSC: What Is the Ultimate Goal?

Launched in 1993 by businesses, environmental organizations, and communities, the FSC is a global forest certification scheme that aims to ensure that products made from forest resources come from responsibly managed forests, which provide a combination of environmental and social benefits (e.g. protecting biodiversity and areas of significant environmental or cultural importance, as well as indigenous peoples' rights, worker's rights, health and safety) (FSC, 2016a). The specific internal contestation outlined here has been ongoing for some years and reached a peak at the general assembly in 2014 when Greenpeace proposed "Motion 65" to set out new requirements for certifying logging companies in "Intact Forest Landscapes” (IFLs) (FSC-Watch, 2014; FSC, 2017). The motion aimed to provide more rigorous protection for IFLs to ensure they remain untouched (FSC-Watch, 2014). Even though 
some claimed this original version of the motion did not go far enough, others, notably some industry representatives, considered it went too far (FSC-Watch, 2014).

After some debates, the original proposal was modified into a new motion looking for consensus among different constituencies and was finally passed (90\% of the members of the general assembly) (Greenpeace, 2015). The final version was restated in such a way that the goal of protecting IFL was somewhat diluted. It did not fully prohibit industrial scale logging from core IFL areas, but rather specified restrictive conditions under which it would be acceptable (FSC, 2017). Thus, even if conditions were hard to meet, the adopted motion made it possible for some products from core IFL areas to carry the FSC label.

Another layer in the complexity of this episode came into play when the Canadian FSC expressed concerns that some industry members could abandon FSC certification if Motion 65 were implemented by the established deadline (FSC, 2016b). While Motion 65 was voted by the international members at the general assembly, any forestry management standard needs to be implemented by the national FSC organizations. If Canadian companies (key suppliers of FSC certified products internationally) rejected the motion, FSC could lose ground with respect to other certifications. The board of directors agreed to prolong the deadline to give the Canadian FSC appropriate time to decide how the protection of IFL should be included in its national standard. In sum, the protection of IFL opened an internal debate at global and national levels within the FSC, which could affect the growth of the certification scheme.

The internal contestation emerging in this episode reveals an underlying disagreement about the ultimate goal of the MSI. According to the FSC Statutes (FSC, 2014) iii $^{\mathrm{ii}}$ the purpose of the organization is "to promote the responsible management of forests, by providing the assistance required to achieve an environmentally appropriate, socially beneficial and 
economically viable use of natural resources and provision of ecosystem services, to avoid deterioration or misuse of such resources, or of the ecosystems or surrounding communities." However, this goal can have different interpretations. Greenpeace and some other environmental NGOs put the emphasis on stopping deforestation and IFL degradation. For others, the goal implies having more and more forests harvested in a responsible manner, claiming that, if appropriately managed, IFLs can be recuperated. Some members believe that the goal of the FSC is to expand as a certification scheme, considering the existence of less stringent and fastergrowing competitors, which are preferred by some firms. Although there are self-interested motives involved in these differences, as the "economic" and the "political" approaches would predict, and there is even the threat (implicit or explicit) that some members will exit and move to another standard, the contestatory deliberative approach emphasizes the benefits of debating, questioning, and presenting challenges insofar as these reinforce the transparency on the different viewpoints about the goal of this MSI and open the possibility of further clarification about the issue.

\section{CONTESTATION AND META-CONSENSUS IN MSIs}

In the previous sections, we have argued that a contestatory deliberative approach discloses how contestation can contribute to the democratic quality of transnational governance mechanisms such as MSIs. We have also identified different types of contestation that can be found within MSIs and the examples have illustrated that contestation can be beneficial. But there cannot be much doubt that contestation can also become a stumbling block for MSIs, limiting their effectiveness, paralyzing deliberation, or fragmenting the organization. Thus, contestation appears to be, at the same time, necessary for MSIs and something they need to 
overcome. How can MSIs manage the co-existence of these two apparently contradictory requirements? In this section, we argue that contestatory deliberation is possible in MSIs thanks to meta-consensus. Meta-consensus - a concept introduced by some contestatory deliberative theorists (Drzyek, 2009; Dryzek \& Niemeyer, 2006; Niemeyer \& Dryzek, 2007)—makes it possible to manage different types of contestation, such as those seen above. This metaconsensus is a basic agreement among all parties on certain principles, such as the right to express one's opinion, the need to respect other parties' opinions, barring the use of force and coercion in trying to defend a point of view, the need to include all affected parties in the discussion, the acceptability of reaching provisional agreements if no consensus is reached, and the possibility to revise previous agreements. This meta-consensus is different from and less demanding than consensus about the decisions that MSIs make with regard to specific issues. It facilitates the ongoing deliberation and the unending process of contestation. Furthermore, it does not undermine the ideal of participants striving for consensus, nor does it entirely exclude provisional aggregative mechanisms.

While meta-consensus is necessary, reaching a final, rational and unanimous consensus on an issue can actually negatively affect the conditions for future deliberation on related issues (see Friberg-Fernros \& Schaffer, 2014). If we accept this, we can argue that the purpose of MSIs is not only the creation of specific, definitive certificates or standards as outcomes (as in the definition above based on Mena \& Palazzo, 2012), but also the continuous revision of provisional agreements based on dialogue, contestation, and exchange within a meta-consensus on some basic principles. The meta-consensus is not to be understood as establishing the lowest common denominator among MSI constituents, but as facilitating a search for mutually 
acceptable outcomes which are better than a compromise of initial positions. Let us explore these ideas in relation to the four types of contestation presented above.

\section{Procedural Contestation}

Contestation about existing rules and procedures, and their application, can spark further discussion about these issues within the MSI, but when contestation is exacerbated could also lead to the collapse of deliberation. MSIs can manage these situations if, despite these disagreements, there is a meta-consensus on the general need to establish and respect procedures (Dryzek \& Niemeyer, 2006) and on the revisable character and possibility of continual improvement of procedural rules. In this sense, further proceduralizing (Reinecke \& Ansari, 2015), understood as reinforcing or revising procedures, is a typical mechanism to manage this type of contestation. In the episode concerning EITI, civil society representatives walked out of the conference and deliberation was put on hold. But, later, further deliberation about new procedures became possible because there was a more basic agreement on the importance of procedures for good governance and a shared understanding on the legitimacy of contestation. Thus, we suggest that MSIs enhance their democratic quality not only if they have well-defined and transparent procedures, but also if they encourage disclosure of procedural breaches and oversights, and if they are open to revising and reinforcing procedures and rules. We also suggest that this is facilitated if there is a meta-consensus among members of the MSI on the general need for governance rules and procedures and on the provisional character of these rules and procedures. In other words, when consensus on the appropriate rule and procedures is lacking, MSIs can move forward thanks to a meta-consensus on the need to have rules and procedures and the need to continue deliberating about them. 


\section{Inclusiveness Contestation}

To prevent this type of contestation from blocking deliberation and, instead, turn it to a productive tension, an MSI requires a meta-consensus that it cannot be isolated from the external world - despite disagreements about who should be represented in the MSI, what would be an equitable and proportional representation, what voices should be heard, and how these voices should express themselves. This shared understanding accepts the MSI as a space of transmission from outside voices - the "public space" - to internal decision-making mechanisms or "empowered space" (Dryzek \& Niemeyer, 2010a). In other words, the MSI is not considered merely as a way for solving a market problem for businesses (i.e. "a space for solutions") or "a space of "settlement" (or bargaining) between different constituencies (Bartley, 2007). In addition, this type of contestation can be managed if there is meta-consensus that disagreements will be respected and that the rules of inclusion can be discussed and revised. Thus, we suggest that MSIs enhance their democratic quality not only if they include different voices and discourses, but also if they encourage questioning, argumentative challenges, and counter-challenges about the inclusion of new voices and discourses. We also suggest that, even if there is no consensus about the specific criteria for inclusion, deliberating about them is possible if there is a meta-consensus among members that the MSI cannot be closed to external viewpoints and its rules of inclusion are susceptible to revision.

\section{Epistemic Contestation}

This type of contestation can be managed if, despite differences in the assessment of the facts related to the social or environmental challenge the MSI tries to address, and the 
consequences of its decisions and policies, there is a meta-consensus that questioning and challenging the veracity of different opinions is necessary in order to build evidence and provide more solid arguments (Bächtiger, 2011). The breakdown of deliberation is avoided if there is a meta-consensus including a shared respect for disputed beliefs, which makes them worth discussing, and an agreement that, on some occasions, it is acceptable to leave aside disputed facts and concentrate on agreed facts while searching for a temporary working agreement. Yet, while a minimum temporary agreement can work in some instances, it could be argued that if it is perceived as a permanent adjournment and a recurrent way out, frustration could grow among some participants who feel the MSI is always avoiding controversy. A further possibility for managing this type of contestation is a provisional agreement on the need to resort to external experts - or another type of third party - to settle differences about facts and consequences. In the episode of Fairtrade International, although the two organizations (Fairtrade International and FTUSA) separated, they maintained a good relationship and agreements were reached concerning geographical scope. One could argue that they mutually accepted the legitimacy of the position of the other party. Despite epistemic disagreements, both sides recognized each other as part of the same movement; hence, they shared a type of meta-consensus. Thus, we suggest that MSIs enhance their democratic quality if they encourage questioning and argumentative challenges and counter-challenges about the facts they are dealing with and the consequences of their decisions and policies. We also suggest that, even without consensus on facts, MSIs can move forward if there is meta-consensus among members on the need to respect disputed beliefs and to provisionally focus on agreed facts with possible recourse to external experts. 


\section{Ultimate-goal Contestation}

This contestation can be turned into a productive tension, rather than an insurmountable obstacle, if constituencies of the MSI share a basic agreement on the legitimacy of different views about the ultimate goal (Niemeyer \& Dryzek, 2007), so that different constituencies mutually recognize the right to disagree about goals and provide reasons to each other for each position. When there is no agreement about the ultimate goal, the different constituencies can also agree to provisionally suspend the "intractables" (Reinecke \& Ansari, 2015), i.e., temporarily avoid the debate. For example, when FSC members revised and approved the new version of Motion 65 in the 2014 general assembly, the "intractable" question of whether there should be parts of the planet that are completely out-of-bounds for logging (even if it could be done in a sustainable way) was temporarily left aside. Yet, as in the previous case, it could be argued that if this is perceived as a permanent adjournment and a recurrent way out, frustration could grow among some participants who feel the MSI is constantly avoiding controversy. Thus, we suggest that MSIs enhance their democratic quality if they encourage questioning and argumentative challenges and counter-challenges about their ultimate goal. We also suggest that, even without consensus about the ultimate goal, MSIs can move forward if there is metaconsensus on the legitimacy of disputed views about that goal, and on the possibility of reaching partial and provisional agreements by temporarily (but not permanently) suspending “intractables".

\section{DISCUSSION: ENHANCING THE DEMOCRATIC QUALITY OF MSIs}

This article explores internal contestation in the transnational governance mechanisms commonly known as MSIs and asks: How can MSIs manage internal contestation, 
acknowledging that it is simultaneously necessary and constraining? We addressed these questions by adopting a contestatory deliberative perspective. This perspective differs from prior studies on MSIs, which focused on their economic rationale for firms' interests ("economic" perspective), power relations between firms, civil society organizations, and government ("political" perspective), or deliberation converging on rational consensus ("deliberative" perspective). Our approach suggests that contestation among members plays a positive role in promoting deliberation and improving the democratic quality of MSIs. This is not captured by understanding MSIs solely as spaces where rational consensus should be reached, as is sometimes done relying on the classic deliberative perspective. Both the agonistic and the classic deliberative perspectives have often assumed a rigid opposition between consensus and contestation. This is a false dichotomy: these two components do not have to be mutually exclusive. Our view offers a more complex pattern of interaction where both consensus and contestation are possible and can lead to a productive tension, as shown in the different types of contestation in MSIs that may emerge among internal constituencies (procedural, inclusiveness, epistemic, and ultimate-goal). The examples from MSIs show that contestation stimulates deliberation even if MSIs do not always reach consensus. Furthermore, the notion of metaconsensus (Dryzek, 2010; Dryzek \& Niemeyer, 2010b) helps understand how questioning, challenging, and contesting discourses can be compatible with the process of deliberation, as it happened in our examples. In other words, meta-consensus facilitates the continuation of a cyclical, ongoing process in which contestation is embedded with deliberation.

\section{Enhancing Democratic Quality in MSIs with Contestation and Meta-consensus}


MSIs have received a number of criticisms; for example, they are seen as leading to a "hegemonic accommodation to dominant interests" (Banerjee, 2017: 10) or allowing corporations to acquire a supervising role that makes them less accountable (Hussain \& Moriarty, 2018). Yet, MSIs can also been seen as imperfect, not fully developed global governance institutions that are susceptible to further democratization (Schouten, Leroy, \& Glasbergen, 2012) and as having the potential to constrain the self-interest of corporations. Several studies on MSIs have inquired into their democratic quality (Scherer \& Palazzo 2011; Schouten \& Glasbergen, 2011; Schouten et al., 2012; Mena \& Palazzo, 2012), following the work of deliberative democracy scholars (Dryzek \& Stevenson, 2011; Nanz \& Steffek, 2005). For example, the analysis of legitimacy of MSIs proposed by Schouten \& Glasbergen (2011) includes three dimensions: legality, moral justification, and consent. Schouten et al. (2012) add inclusiveness, authenticity, and consequentiality as three key elements to assess the deliberative capacity of MSIs. Mena and Palazzo (2012) claim that input legitimacy is influenced by stakeholder inclusion, procedural fairness, promotion of a consensual orientation, and transparency of the MSI's structures and process.

Our research complements these proposals arguing that the promotion of contestation is another important, albeit underestimated, dimension of the democratic quality of MSIs. Without the different participants discussing, questioning, challenging, and counter-challenging their concerns about procedures, inclusion, transparency, structures, impacts of the decisions, and the ultimate-goal of the MSI, the prospects for these mechanisms of transnational governance to democratize and move towards being deliberative forums would diminish. Contestation and self-examination are part of a healthy deliberative system, since deliberative practices themselves should be open to deliberation and change (Dryzek 2010; Gutmann \& Thompson 
2004). The contestatory deliberative perspective allows us to emphasize that, without such contestation, MSIs are more likely to remain spaces that corporations use for their market needs, as predicted by the economic approach to MSIs. The contestatory deliberative approach also shows that contestation does not cause the breakdown of deliberation if there is meta-consensus about the need to include and respect multiple contested discourses, values, and preferences, to continue deliberating, and to reach provisional agreements that can be improved later.

Our article also suggests that the definition of MSIs, based on the work by Mena \& Palazzo (2012) introduced earlier, should be expanded to include the dynamic of ongoing revision as one of their characteristics. As some recent deliberative democrats have pointed out, reaching a final consensus could mean putting an end to further deliberation (Friberg-Fernros \& Schaffer, 2014). Thus, since multiple opinions and disagreement are necessary for deliberation, the democratization of MSIs requires that a consensual closure is not reached and that they remain open to continuous revisions. Yet, even if it is not reached, the ideal of consensus can still be present and is not incompatible with the reality of diversity and fallback provisional solutions like temporary agreements (Friberg-Fernros \& Schaffer, 2014).

\section{Extending Contestation to Deliberation in the Political CSR Field}

Our work extends the normative analysis of Scherer and Palazzo (2007) about the new role for business as a political actor in a Post-Westphalian political order. We do not enter here into the question of whether corporations are appropriate sites for deliberation (internally as a whole or some parts of it), which has recently received criticism (Sabadoz \& Singer, 2017). One could deny this aspect and still think that, when they participate in forums such as MSIs which set rules of conduct for social and environmental issues, corporations should be subjected to 
standards stemming from deliberative democratic theory. For, in joining MSIs, as opposed to joining business-led private governance initiatives (Marques, 2013), corporations enter global governance mechanisms over which there are increasing expectations to address the often-cited democratic deficit.

By adopting a contestatory deliberative approach to study MSIs, we stress that they are imperfect deliberative and contested forums, constantly revising their processes, goals, inclusion criteria, and assessments as they attempt to establish forms of private regulation for social and environmental challenges. Scherer \& Palazzo's (2007) description of the deliberative role of business in global society has been criticized for being too idealistic and possibly excluding marginalized voices (Edward \& Wilmott, 2013; Banerjee \& Sabadoz, 2014). Focusing too narrowly on rational consensus might indeed leave only two choices: playing by the rules or destructive confrontation (leading to frustration and impotence). Paying more attention and granting higher value to internal contestation, in line with recent tendencies in deliberative theory (Mansbridge et al, 2010; Bächtiger et al, 2010; Dryzek, 2010; Chambers, 2003), can show that the democratization of these spaces, even if it is still a long way from being fulfilled today, is desirable and possible.

Unfortunately, internal contestation has also been omitted by scholars analyzing MSIs from other perspectives such as the neo-institutional one (Rasche, 2012; Gilbert et al., 2011). Yet, some rare contributions might be closer to the approach adopted in this article, such as the “dissensual CSR" proposed by Whelan (2013), which starts with a criticism of the notion of political CSR as focusing too exclusively on consensus and underlines the productive aspects of disagreement and differences. Taking a sense-making approach to study Fairtrade International, Reinecke and Ansari do not focus either on consensus as an inevitable outcome; rather, they 
show how participants refine and redraft their emergent interpretations of ethical issues and "learn from one another to reach provisional ethical truces based on varying degrees of shared meaning" (Reinecke \& Ansari, 2015: 884). Our approach complements these contributions by highlighting that "provisional ethical truces" and "dissensus" are not only compatible but facilitated by a meta-consensus; a thinner and more basic version of consensus than the one usually portrayed.

The notion of meta-consensus sets our proposal apart from that of agonistic pluralism (Mouffe, 1999; Dawkins, 2015). While our view resembles this perspective in that it values plurality and conflict, we claim that these aspects are embraced by the contestatory deliberative approach. According to this approach, power struggles do not determine the legitimacy of outcomes and processes; and one needs to emphasize complementarity, rather than a dichotomy, between cherishing contestation and attempting to distinguish between legitimate and illegitimate institutions. We argue that this approach can bring new light to the study of MSIs and other aspects of the relationship between firms and their stakeholders.

\section{Future Research}

This article opens several possibilities for research. While we have proposed four types of internal contestation in MSIs and provided an illustrative example for each, further work is required to build a broader empirical base for this typology and explore the possibility of new types. Future empirical research such as in depth longitudinal cases of MSIs would be necessary to study further how meta-consensus allows the management of contestation and to see how this combination increases deliberation and democratic quality. Cases of contestation within MSIs which were ultimately not resolved and led to an escalation of adversarial practices could add 
valuable insights to this discussion, as a contrast to those cases in which meta-consensus made deliberation possible. While we have argued that contestation is necessary, the question of the appropriate level of contestation that an MSI can tolerate cannot be answered theoretically; but the factors on which this question depends would be worth analyzing with empirical research.

Our focus in this article has been internal contestation. But this is just one potential path to democratize MSIs. External challenges, including unfriendly criticisms, can clearly be another driving force. Therefore, combining the analysis of internal and external contestation would be important to research. Research that takes into account different levels of analysis could also offer insights into elements at the individual level such as trust among participants as a factor that makes the combination of contestation and meta-consensus more likely. Further work could also inquire more specifically about the role of firms in MSIs: How do they acquire the capabilities necessary to participate in deliberative forums where the language cannot be only that of bargaining and power dynamics?

Our analysis of internal contestation did not focus on the role of governments, which are members of only some MSIs (such as EITI), but not of others. Governments can clearly play a variety of roles such as promoting and demanding higher democratic quality of MSIs, mediating in cases in which the parties disagree, and promoting (or discouraging) the expansion of a particular MSI at a national level (perhaps due to the importance of the industry being regulated by the MSI for the national economy). These different roles could be studied in relation to the combination of contestation and deliberation. These questions would lead to inquire about the interaction between national and international regulations and MSI standards (as done by Knudsen \& Moon, 2017) as well as how MSIs depend on multiple political environments and institutional frameworks. Studying these interactions raises further questions about how the 
overall democratic quality of the wider system can influence the democratic quality of MSIs. Much criticism has been about the possible negative impact of MSIs over the wider deliberative system, but this would require empirical evidence, and perhaps democratizing MSIs can also influence the democratic quality of the wider system. Moreover, it would be worth examining whether the existence of multiple MSIs with similar agendas (and possibly in competition) might increase or diminish their democratic quality.

A different aspect that would deserve further inquiry is the relationship between contestation and coercion in MSIs. As mentioned earlier, both the classic and the contestatory deliberative approach share the condition of excluding coercive power from deliberation. As Mansbridge and her colleagues put it: "Participants should not try to change others' behaviors through the threat of sanction or the use of force" (Mansbridge et al., 2010: 66). The absence of coercive power is a regulative ideal, serving as a standard against which to measure practice. Our argument implies that actors in MSIs are expected to engage in contestation without the use of coercive power. Yet, what counts as coercion? Would it include the threat of abandoning an MSI? If so, the challenge would be to design MSIs so that parties (especially firms, as mentioned in the FSC case above) cannot use that threat. This raises difficult questions such as: Does this mean that there should not be voluntary exit from MSIs? Or under what circumstances could one use this "threat"? And, more generally, can one envision exceptions to the rule barring coercive power? For example, it has been argued that in case of large preexisting inequalities, some coercion can be justified to maintain equal opportunity as well as to push for other conditions conducive to the deliberative ideal (Mansbridge et al., 2010). These are complex and controversial questions that the literature on MSIs needs to address in the future. 


\section{Practical Implications}

This research has important implications at the practitioner level. First, it suggests that the complete absence of contestation in an MSI should be interpreted as a sign that its democratic quality is diminishing and it is moving towards a bureaucracy or a private club. At the same time, ignoring contestation or managing it in a clearly non-deliberative way (e.g. suppressing it) are not feasible strategies for an MSI if it wants to maintain legitimacy and avoid breakdown. The analysis of internal contestation offered here might be useful to MSI members to understand which of the four types of contestation they are facing in a given situation, as well as which aspects of meta-consensus they need to stress in order to manage them. Finally, for companies, this analysis would lead them to comprehend that when they join MSIs, they are entering forums over which there are expectations of further democratization, and not only spaces of bargaining and negotiation.

\section{CONCLUSION}

Given that electoral accountability and constitutional representation are not applicable to new forms of transnational governance (Biermann \& Gupta, 2011) such as MSIs, one needs to consider other aspects to assess their democratic quality. The main criticism advanced against those using Habermas' views on "rational deliberation" to discuss the political role of the corporation and of transnational private regulation initiatives such as MSIs is that their approach is an idealized conceptualization of deliberative democracy. Instead, in this article, we suggested a contestatory deliberative approach that attaches higher value to pluralism and contestation. According to this approach, allowing for and managing internal contestation is a fundamental part of the democratization process; an aspect underestimated by previous studies. 
While some have seen MSIs as an opportunity for "the democratization of corporate decision-making” (Scherer, Palazzo \& Baumann, 2006: 523), others consider them as “depoliticization mechanisms that limit political expression and struggle" (Moog et al., 2015: 474; Banerjee, 2017). An exploration of contestation and meta-consensus within MSIs allows scholars to move beyond both assumptions: that MSIs are the solution and that they are the obstacle for democratic global governance. As Elinor Ostrom wrote: "'getting the institutions right' is a difficult, time-consuming, conflict-invoking process" (Ostrom, 1990: 14). If MSIs continue being a fundamental piece in the puzzle of transnational governance, how they deal with contestation will become highly relevant for discussions concerning their democratic quality as well as their effectiveness.

\section{ACKNOWLEDGEMENTS}

The authors are very grateful to the editor and the anonymous reviewers for their comments in developing this article. We would like to acknowledge the valuable feedback we received from Andreas Scherer and other participants at the workshop on Political CSR: Paper Development Roundtable 2016, organized by ETHOS Center at Cass Business School, City University, London. This project received funding from the Campus of International Excellence "Aristos Campus Mundus".

\section{NOTES}

\footnotetext{
${ }^{\mathrm{i}}$ The Discourse Quality Index (DQI) proposed by Steiner et al (2004) includes four key indicators: 1) level of justification (claims supported by well-defined justifications); 2) content of justification (concern for common good); 3) respect for others; and 4) reciprocity (willingness to consider alternative views). Nanz and Steffek (2005) identify four key indicators of democratic quality in decision-making: 1) access to deliberation; 2) transparency and
} 
access to information; 3) responsiveness to stakeholder concerns; 4) inclusion of all voices. De Vries et al. (2011) include three middle-order indicators of the quality of democratic deliberation: 1) process (facilitation, equality of participation, participant engagement and respect); 2) information (use of on-site experts, use of incorrect information, learning new information, understanding and application of information and impact of information on opinions); and 3) reasoning (justification of opinion, openness to complexity, adoption of a societal perspective). ii This includes that the elite capture of wealth, community tensions, and corruption, which impede economic development (Mehlum, Moene \& Torvick, 2006).

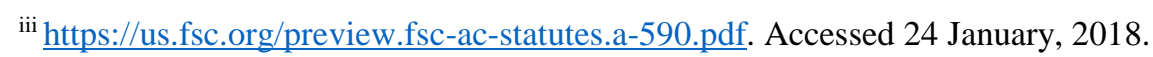




\section{REFERENCES}

Aaronson, S. A. 2011. Limited partnership: Business, government, civil society, and the public in the Extractive Industries Transparency Initiative (EITI). Public Administration and Development, 31: 50-63.

Agbiboa, D. 2012. Between corruption and development: The political economy and State robbery in Nigeria. Journal of Business Ethics, 108: 325-345.

Bächtiger, A., 2011. Contestatory deliberation. Paper presented at Epistemic Democracy Conference, Yale University, New Haven, USA, 22 October.

Bächtiger, A., Niemeyer, S., Neblo, M., Steenbergen, M. R., \& Steiner, J. 2010. Disentangling diversity in deliberative democracy: Competing theories, their blind spots and complementarities. Journal of Political Philosophy, 18(1): 32-63.

Bäckstrand, K. 2006. Multi-stakeholder partnerships for sustainable development: Rethinking legitimacy, accountability and effectiveness. European Environment, 16: 290-206.

Banerjee, S.B. 2018. Transnational power and translocal governance: The politics of corporate responsibility. Human Relations, 7(6): 796-821.

Banerjee, S. B., \& Sabadoz, C. 2014. The governance of political corporate social responsibility. Academy of Management Proceedings, 1: 16194.

Bartley, T. 2007. Institutional emergence in an era of globalization: The rise of transnational private regulation of labor and environmental conditions. American Journal of Sociology, 113(2): 297-351.

Baur, D., \& Arenas, D. 2014. The value of unregulated business-NGO interaction a deliberative perspective. Business \& Society, 53(2): 157-186. 
Biermann, F., \& Gupta, A. 2011. Accountability and legitimacy in Earth system governance: A research framework. Ecological Economics, 70 (11): 1856-1864.

Brady, J. S. 2004. No contest? Assessing the agonistic critiques of Jürgen Habermas's theory of the public sphere. Philosophy \& Social Criticism, 30(3): 331-354.

Brunsson, N., Rasche, A., \& Seidl, D. 2012. The dynamics of standardization: Three perspectives on standards in organization studies. Organization Studies, 33(5-6): 613-632.

Cashore, B. 2002. Legitimacy and the privatization of environmental governance: How nonstate market-driven (NSMD) governance systems gain rule-making authority. Governance, 15(4): 503-529.

Chambers, S. 2003. Deliberative democratic theory. Annual Review of Political Science, 6(1): 307-326.

Cropanzano, R., Bowen, D. E., \& Gilliland, S. W. 2007. The management of organizational justice. Academy of Management Perspectives, 21(4): 34-48.

Dawkins, C. 2015. Agonistic pluralism and stakeholder engagement. Business Ethics Quarterly, 25(1): 1-28.

Detomasi, D. A. 2007. The multinational corporation and global governance: Modelling global public policy networks. Journal of Business Ethics, 71(3): 321-334.

De Vries, R., Stanczyk, A. E., Ryan, K. A., \& Kim, S. Y. 2011. A framework for assessing the quality of democratic deliberation: Enhancing deliberation as a tool for bioethics. Journal of Empirical Research of Human Research Ethics, 6 (3): 3-17.

Diamond, L. J., \& Morlino, L. 2004. An overview. Journal of Democracy, 15(4): 20-31.

Djelic, M. L., \& Sahlin-Andersson, K. (Eds.). 2006. Transnational governance: Institutional dynamics of regulation. Cambridge: Cambridge University Press. 
Dryzek, J. S. 1999. Transnational democracy. Journal of Political Philosophy, 7(1): 30-51.

Dryzek, J. S. 2000. Deliberative democracy and beyond: Liberals, critics, contestations. Oxford: Oxford University Press.

Dryzek, J. S., 2005. Deliberative democracy in divided societies. Political Theory, 33(2): 218242.

Dryzek, J. S. 2010. Foundations and frontiers of deliberative democracy. Oxford: Oxford University Press.

Dryzek, J.S., \& Niemeyer, S. 2006. Reconciling pluralism and consensus as political ideals. American Journal of Political Science, 50 (3): 634-649.

Dryzek, J. S., \& Niemeyer, S. 2010a. Representation. In Dryzek, J.S. Foundations and frontiers of deliberative democracy: 42-65. Oxford: Oxford University Press.

Dryzek, J. S., \& Niemeyer, S. 2010b. Pluralism and metaconsensus. In Dryzek, J.S. Foundations and frontiers of deliberative democracy: 85-113. Oxford: Oxford University Press.

Dryzek, J. S., \& Stevenson, H. 2011. Global democracy and earth system governance. Ecological Economics, 70(11): 1865-1874.

Economist, The. 2016, February 25. Flare-up. https://www.economist.com/news/business/21693596-tensions-run-high-international$\underline{\text { transparency-initiative-flare-up }}$

Edward, P., \& Willmott, H. 2013. Discourse and normative business ethics. In Lutge, C. (Ed.), Handbook of the philosophical foundations of business ethics: 549-580. New York: Springer. 
EG Justice, 2016, March 12. EITI: Lingering questions. http://www.egjustice.org/post/eitilingering-challenges

EITI. 2016, April 7. 33rd EITI Board Meeting Minutes. Extractive Industries Transparency Initiative International Secretariat. https://eiti.org/files/BP/minutes_33nd_eiti_board_meeting-lima.pdf

EITI. 2017, May 24. The EITI Standard 2016. Extractive Industries Transparency Initiative International Secretariat. https://eiti.org/sites/default/files/documents/the_eiti_standard_2016___english.pdf

Fairtrade International. 2011. About. http://www.fairtrade.net/about-fairtrade/who-we-are.html, accessed 23 September, 2016.

Fairtrade International. 2012, February 23. U.S. Stakeholder Consultations: Fairtrade Labelling Organizations (FLO). Sustainability What's Next. Key Findings / November 2011. http://www.fairtrade.net/fileadmin/user_upload/content/2009/resources/2012-02-20fairtrade-intl_usa-dialogue_key-findings-final.pdf

Fairtrade USA. 2011, September 15. Fair Trade USA Resigns Fairtrade International (FLO) Membership. http://fairtradeusa.org/press-room/press_release/fair-trade-usa-resignsfairtrade-international-flo-membership, accessed 23 September, 2016.

Fransen, L. 2012. Multi-stakeholder governance and voluntary programme interactions: legitimation politics in the institutional design of Corporate Social Responsibility. SocioEconomic Review, 10(1): 163-192.

Fransen, L.W., \& Kolk, A. 2007. Global rule-setting for business: A critical analysis of multistakeholder standards. Organization, 14(5): 667-684. 
Fraser, N. 1997. Structuralism or pragmatics? On discourse theory and feminist politics. In Nicholson, L. (Ed.). The second wave: a reader in feminist theory: 379-395. New York: Routledge.

Friberg-Fernros, H., \& Schaffer, J.K. 2014. The consensus paradox: Does deliberative agreement impede rational discourse? Political Studies, 62(1): 99-116.

Frynas, J. G. 2010. Corporate social responsibility and societal governance: Lessons from transparency in the oil and gas sector. Journal of Business Ethics, 93: 163-179.

FSC. 2014. Statutes July 2013-Sept 2014. Forest Stewardship Council. https://us.fsc.org/preview.fsc-ac-statutes.a-589.pdf

FSC. 2016a. Importance of Forest Stewardship. Forest Stewardship Council. https://ic.fsc.org/en/our-impact/importance-of-forest-stewardship, accessed 11 June, 2016.

FSC. 2016b. Certification. Forest Stewardship Council. https://us.fsc.org/en-us/certification, accessed 11 June, 2016.

FSC. 2017. FSC General Assembly 2017. IFL Global progress. Vancouver, Canada, 8-13 October. Forest Stewardship Council. https://ga2017.fsc.org/wp-content/uploads/2017/11/1IFL-side-event-global-introduction-by-Pasi.pdf

FSC-Watch. 2014, September 18. Greenpeace loses the plot: Motion 65 Shambles, and an Ugly Failure to Protect 'Intact Forests'. https://fsc-watch.com/2014/09/18/greenpeaceloses-the-plot-motion-65-shambles-and-an-ugly-failure-to-keep-the-fsc-strong/

Gilbert, D. U., \& Rasche, A. 2007. Discourse ethics and social accountability: The ethics of SA 8000. Business Ethics Quarterly, 17(02): 187-216.

Gilbert, D. U., Rasche, A., \& Waddock, S. 2011. Accountability in a global economy: The emergence of international accountability standards. Business Ethics Quarterly, 21: 23-44. 
Greenpeace. 2015, September 14. Proud to be part of FSC at its best. http://www.greenpeace.org/international/en/news/Blogs/makingwaves/fsc-protecting-intactforest-landscapes-motion-65/blog/54053/

Gunter, M. 2012. A schism over Fair Trade. http://www.marcgunther.com/a-schism-over-fairtrade/, accessed 23 September, 2016.

Gutmann, A., \& Thompson, D. 2004. Why deliberative democracy. Princeton: Princeton University Press.

Habermas, J. 1994. Three normative models of democracy. Constellations, 1(1): 1-10.

Habermas, J. 1995. Reconciliation through the public use of reason. Journal of Philosophy, 92(3): 109-131.

Habermas, J. [1995] 2015. Between facts and norms: Contributions to a discourse theory of law and democracy. New York: John Wiley \& Sons.

Haight, C. 2011. The problem with fair trade coffee. Stanford Social Innovation Review, 3: 7479.

Haufler, V. 2010. Disclosure as governance: The Extractive Industries Transparency Initiative and resource management in the developing World. Global Environmental Politics, 10(3): 53-73.

Hussain, W., \& Moriarty, J. 2018. Accountable to whom? Rethinking the role of corporations in political CSR. Journal of Business Ethics, 149(3), 519-534.

Knudsen, J. S., \& Moon, J. 2017. Visible hands: Government regulation and international business responsibility. Cambridge, UK: Cambridge University Press.

Levy, D.L., \& Egan, D. 2003. A neo-Gramscian approach to corporate political strategy: conflict and accommodation in the climate change negotiations. Journal of Management 
Studies, 40: 803-829.

Mansbridge, J., Bohman, J., Chambers, S., Estlund, D., Føllesdal, A., Fung, A., Lafont, C., Manin, B., \& Martí, J. L. 2010. The place of self-interest and the role of power in deliberative democracy. Journal of Political Philosophy, 18(1): 64-100.

Markell, P. 1997. Contesting consensus: Rereading Habermas on the public sphere. Constellations, 3(3): 377-400.

Marques, J. C. 2013. A league of their own: How business--led private governance initiatives achieve legitimacy. PhD Thesis. McGill University, Montreal.

Matten, D., \& Crane, A. 2005. Corporate citizenship: Toward an extended theoretical conceptualization. Academy of Management Review, 30: 166-179.

Mehlum, H., Moene, K., \& Torvik, R. 2006. Institutions and the resource curse. The Economic Journal, 116(508): 1-20.

Mena, S., \& Palazzo, G. 2012. Input and output legitimacy of multi-stakeholder initiatives. Business Ethics Quarterly, 22(3): 527-556.

Modelo, M. 2014. The paradox of fair trade. Stanford Social Innovation Review, 12(1): 40-45. Moog, S., Spicer, A., \& Böhm, S. 2015. The politics of multi-stakeholder initiatives: The crisis of the Forest Stewardship Council. Journal of Business Ethics, 128: 469-493.

Moore, G. 2004. The fair trade movement: Parameters, issues and future research. Journal of Business Ethics, 53(1-2): 73-87.

Mouffe, C. 1999. Deliberative democracy of agonistic pluralism? Social Research, 66(4): 74558.

Nanz, P., \& Steffek, J. 2005. Assessing the democratic quality of deliberation in international governance: Criteria and research strategies. Acta Politica, 40: 368-383. 
Niemeyer, S. 2011. The emancipatory effect of deliberation: Empirical lessons from minipublics. Politics \& Society, 39(1): 103-140.

Niemeyer, S., \& Dryzek, J. S. 2007. The ends of deliberation. Meta-consensus and intersubjective rationality as ideal outcomes. Swiss Political Science Review, 13(4): 497-526.

Ölcer, D. 2009, March 11. Extracting the Maximum from the EITI. OECD Working Paper No. 276. Organisation for Economic Co-operation and Development. https://www.oecdilibrary.org/docserver/225520261678.pdf?expires=1560864461\&id=id\&accname=guest \&c hecksum=4EA8BA4CF55F44E49194BFD438EAB3EC

Ostrom, E. 1990. Governing the commons. The evolution of institutions for collective action. Cambridge, UK: Cambridge University Press.

Pinske, J., \& Kolk, A. 2012. Addressing the climate change - Sustainable development nexus: The role of multistakeholder partnerships. Business \& Society, 51: 176-210.

Potoski, M., \& Prakash, A. 2009. Voluntary programs: A club theory perspective. Cambridge, MA: MIT Press.

PWYP. 2016, February 24. Statement: EITI Governance Failures Threaten Independent Civil Society. Publish What You Pay. http://www.publishwhatyoupay.org/pwyp-news/statement$\underline{\text { eiti-governance-failures-threaten-independent-civil-society/ }}$

Rasche, A. 2012. Global policies and local practice: Loose and tight couplings in multistakeholder initiatives. Business Ethics Quarterly, 22: 679-708.

Reinecke, J. \& Ansari, S. 2015. What is a "fair" price? Ethics as sensemaking. Organization Science, 26(3): 867-888. 
Rice, P. 2012, January 11. Fair Trade USA: Why We Parted Ways with Fair Trade International. TriplePundit.com. http://www.triplepundit.com/2012/01/fair-trade-all-fairtrade-usa-plans-double-impact-2015/

RSPO. 2013. Approved Minutes Roundtable on Sustainable Palm Oil 10th General Assembly. Roundtable on Sustainable Palm Oil. https://www.rspo.org/library/lib_files/preview/292

Sabadoz, C., \& Singer, A. 2017. Talk ain't cheap: Political CSR and the challenges of corporate deliberation. Business Ethics Quarterly, 27(2): 183-211.

Sachs, J. D., \& Warner, A. M. 2001. The curse of natural resources. European Economic Review, 45(4): 827-838.

Santoro, M. A. 2010. Post-Westphalia and its discontents: Business, globalization, and human rights in political and moral Perspective. Business Ethics Quarterly, 20(2): 285-297.

Scherer, A. G., \& Palazzo, G. 2007. Toward a political conception of corporate responsibility: Business and society seen from a Habermasian perspective. Academy of Management Review, 32(4): 1096-1120.

Scherer, A.G., \& Palazzo, G. 2011. The new political role of business in a globalized world: A review of a new perspective on CSR and its implications for the firm, governance and democracy. Journal of Management Studies, 48(4): 899-931.

Scherer, A. G., Palazzo, G., \& Baumann, D. 2006. Global rules and private actors: Toward a new role of the transnational corporation in global governance. Business Ethics Quarterly, 16(4):505-532.

Scherer, A. G., Palazzo, G., \& Matten, D. 2009. Introduction to the special issue: Globalization as a challenge for business responsibilities. Business Ethics Quarterly, 19: 327-48. 
Schouten, G., \& Glasbergen, P. 2011. Creating legitimacy in global private governance: The case of the Roundtable on Sustainable Palm Oil. Ecological Economics, 70(11): 18911899.

Schouten, G., Leroy, P., \& Glasbergen, P. 2012. On the deliberative capacity of private multistakeholder governance: The Roundtables on Responsible Soy and Sustainable Palm Oil. Ecological Economics, 83: 42-50.

Smith, G. 2009. Democratic innovations: Designing institutions for citizen participation. Cambridge, UK: Cambridge University Press.

Steiner, J., Bächtiger, A., Spörndli, M., \& Steenbergen, M. R. 2004. Deliberative politics in action: Analyzing parliamentary discourse. Cambridge, UK: Cambridge University Press.

Stevenson, H., \& Dryzek, J. S. 2014. Democratizing global climate governance. Cambridge, UK: Cambridge University Press.

Turcotte, M. F., Reinecke, J., \& den Hond, F. 2014. Explaining variation in the multiplicity of private social and environmental regulation: a multi-case integration across the coffee, forestry and textile sectors. Business and Politics, 16(1): 151-189.

Whelan, G. 2013. Corporate constructed and dissent enabling public spheres: Differentiating dissensual from consensual corporate social responsibility. Journal of Business Ethics, 115(4): 755-769.

Zeyen, A., Beckmann, M., \& Wolters, S. 2016. Actor and institutional dynamics in the development of multi-stakeholder initiatives. Journal of Business Ethics, 135(2): 341-360. 
Table 1. Different approaches to MSIs and their account of internal contestation

\begin{tabular}{|c|c|c|}
\hline MSIs approach & MSIs as spaces for & Account of internal contestation \\
\hline Economic perspective & $\begin{array}{l}\text { MSIs as spaces for market } \\
\text { solutions }\end{array}$ & $\begin{array}{l}\text { Contestation appears as a result of } \\
\text { different economic and market interests } \\
\text { Internal contestation as a risk and a cost } \\
\text { Possibility that the desire to avoid internal } \\
\text { contestation leads to multiplicity of } \\
\text { standards }\end{array}$ \\
\hline Political perspective & $\begin{array}{l}\text { MSIs as spaces for political } \\
\text { conflict and bargaining }\end{array}$ & $\begin{array}{l}\text { Contestation emerges from differences of } \\
\text { power between actors with divergent } \\
\text { interests and discourses } \\
\text { Contestation leads to actors questioning } \\
\text { each other's legitimacy }\end{array}$ \\
\hline Deliberative perspective & $\begin{array}{l}\text { MSIs as spaces of } \\
\text { participatory deliberation } \\
\text { and legitimate rational } \\
\text { consensus }\end{array}$ & $\begin{array}{l}\text { Contestation emerges as problematic and } \\
\text { a distraction, and should be } \\
\text { overcome/resolved }\end{array}$ \\
\hline $\begin{array}{l}\text { Contestatory deliberative } \\
\text { perspective }\end{array}$ & $\begin{array}{l}\text { MSIs as spaces of } \\
\text { contestation, deliberation, } \\
\text { and meta-consensus }\end{array}$ & $\begin{array}{l}\text { Contestation is core to improve the } \\
\text { democratic quality of MSIs } \\
\text { Meta-consensus allows actors to accept } \\
\text { provisional agreements to continue } \\
\text { deliberation and accept further } \\
\text { contestation }\end{array}$ \\
\hline
\end{tabular}


Table 2: Summary of the MSIs used in the illustrative episodes

\begin{tabular}{|c|c|c|c|c|}
\hline & EITI & RSPO & Fairtrade & FSC \\
\hline Contestation & Procedural & Inclusiveness & Epistemic & Ultimate-goal \\
\hline Sector & Extractives & Palm oil & Commodity trading & Forestry \\
\hline $\begin{array}{l}\text { Founded/ } \\
\text { launched }\end{array}$ & 2003 & 2004 & 1997 & 1993 \\
\hline $\begin{array}{l}\text { Main } \\
\text { objective }\end{array}$ & $\begin{array}{l}\text { Achieve transparency } \\
\text { in payments between } \\
\text { firms and } \\
\text { governments. Raise } \\
\text { awareness. }\end{array}$ & $\begin{array}{l}\text { Promote the sustainable } \\
\text { production, procurement, and use } \\
\text { of palm oil. }\end{array}$ & $\begin{array}{l}\text { Help small farmers } \\
\text { organized into small } \\
\text { cooperatives to improve } \\
\text { their working conditions } \\
\text { and economic benefits. }\end{array}$ & $\begin{array}{l}\text { Ensure forests are } \\
\text { responsibly managed } \\
\text { and provide social and } \\
\text { environmental benefits } \\
\text { Avoid deforestation. }\end{array}$ \\
\hline Standards & EITI Standard & RSPO Standard & $\begin{array}{l}\text { FLO Fairtrade standards: } \\
\text { produce support. } \\
\text { FLO-CERT certification } \\
\text { (producer organizations } \\
\text { and audit traders). }\end{array}$ & FSC Certification \\
\hline Members & $\begin{array}{l}3 \text { constituencies: } \\
\text { government, business } \\
\text { and civil society. } \\
\text { Each elects } \\
\text { representatives } \\
\text { differently. PWYP } \\
\text { manages the voting } \\
\text { process for } \\
\text { representatives of } \\
\text { civil society } \\
\text { organizations } \\
\end{array}$ & $\begin{array}{l}7 \text { stakeholder groups representing } \\
\text { the palm oil supply chain: } \\
\text { - Oil palm producers } \\
\text { - Palm oil processors and traders } \\
\text { - Consumer goods manufacturers } \\
\text { - Retailers } \\
\text { - Banks and investors } \\
\text { - Environmental or nature } \\
\text { conservation NGOs } \\
\text { - Social or developmental NGOs }\end{array}$ & $\begin{array}{l}\text { Fairtrade International } \\
\text { involves three producer } \\
\text { networks, } 25 \text { Fairtrade } \\
\text { organizations, Fairtrade } \\
\text { International, and } \\
\text { FLOCERT, the } \\
\text { independent certification } \\
\text { body of the global } \\
\text { Fairtrade system. }\end{array}$ & $\begin{array}{l}\text { Environmental, social } \\
\text { and economic } \\
\text { chambers. Each } \\
\text { chamber has } 50 \% \\
\text { votes for north and } \\
\text { south. }\end{array}$ \\
\hline Impact & $\begin{array}{l}51 \text { countries partially } \\
\text { compliant and } 31 \\
\text { countries fully } \\
\text { compliant with } \\
\text { standard (2016). } \\
\$ 1.85 \text { trillion of } \\
\text { government revenues } \\
\text { disclosed. }\end{array}$ & $\begin{array}{l}\text { In May 2016, RSPO includes } \\
120,655 \text { individual smallholders } \\
\text { and } 283,216 \text { hectares of } \\
\text { smallholders as certified areas. In } \\
\text { total } 11 \text { million tons are certified } \\
\text { globally ( } 17 \% \text { of global palm oil } \\
\text { in the world). }\end{array}$ & $\begin{array}{l}\text { In } 2015,1.5 \text { million small- } \\
\text { scale farmers and workers } \\
\text { around the world } \\
\text { participated in the } \\
\text { Fairtrade system and } \\
\text { benefit from Fairtrade. }\end{array}$ & $\begin{array}{l}\text { In May } 2016 \text { the total } \\
\text { forest area of } \\
188,385,242 \text { ha } \\
\text { worldwide distributed } \\
\text { among } 81 \text { countries } \\
\text { was under the FSC } \\
\text { management } \\
\text { certification }\end{array}$ \\
\hline
\end{tabular}




\section{Authors biographies:}

Daniel Arenas is Associate Professor at ESADE Business School-Universitat Ramon Llull in Barcelona, where is also the Chair of the Department of Social Sciences and a member of the Institute for Social Innovation. He has done research on the dynamics of conflict and collaboration between firms and NGOs, and firms and communities; stakeholder theory; political CSR; as well as business obligations towards future generations. His work has been published in different journals such as Organization Studies, Organization \& Environment, Business \& Society, and Journal of Business Ethics.

Laura Albareda is Associate Professor at the School of Business and Management of Lappeenranta University of Technology, Finland. Her primary areas of research interest are business sustainability, business collective action and polycentric governance, and political CSR. She also works on sustainability-oriented innovation, value creation and sustainable business models. She has published her work in Journal of Business Ethics, Journal of Business Research, and Business and Society. She has been visiting scholar at Ivey Business School, Amsterdam Business School, Boston University and Warwick University. Her article 'Polycentric governance of privately owned resources in Circular Economy Systems', co- authored by Patala, Albareda \& Halme has been awarded by the All-Academy Best International Paper Award 2018 at the Academy of Management Annual Meeting, Chicago, August 2018.

Jennifer Goodman is Associate Professor in the Department of Business and Society at Audencia Business School, France. Her research and teaching interests lie broadly in the relationship between business, government and society, sustainability and CSR. More 
specifically her research projects focus on sustainability-oriented innovation, stakeholder collaboration, the political role of corporations, governance, and responsible investment. These projects have led to publications in academic journals such as Business Ethics Quarterly, Journal of Business Ethics, Business Strategy and the Environment, and Society \& Business Review, as well as a chapter in the book "Shareholder Empowerment: A New Era in Corporate Governance". 